\title{
A Strategy to Revalue a Wood Waste for Simultaneous Cadmium Removal and Wastewater Disinfection
}

\author{
Aleksandra Ivanovska $\left(\mathbb{D},{ }^{1}\right.$ Sonja Veljović $\left(\mathbb{D},{ }^{2}\right.$ Biljana Dojčinović $\left(\mathbb{D},{ }^{3}\right.$ Nenad Tadić, ${ }^{4}$ \\ Katarina Mihajlovski $\mathbb{D}^{5}{ }^{5}$ Maja Natić $\mathbb{D}^{6},{ }^{6}$ and Mirjana Kostić ${ }^{5}{ }^{5}$ \\ ${ }^{1}$ University of Belgrade, Innovation Center of the Faculty of Technology and Metallurgy, Belgrade 11000, Serbia \\ ${ }^{2}$ Institute of General and Physical Chemistry, Belgrade 11000, Serbia \\ ${ }^{3}$ University of Belgrade, Institute of Chemistry, Technology and Metallurgy, Belgrade 11000, Serbia \\ ${ }^{4}$ University of Belgrade, Faculty of Physics, Belgrade 11000, Serbia \\ ${ }^{5}$ University of Belgrade, Faculty of Technology and Metallurgy, Belgrade 11000, Serbia \\ ${ }^{6}$ University of Belgrade, Faculty of Chemistry, Belgrade 11158, Serbia \\ Correspondence should be addressed to Aleksandra Ivanovska; aivanovska@tmf.bg.ac.rs
}

Received 31 May 2021; Revised 25 June 2021; Accepted 23 July 2021; Published 13 August 2021

Academic Editor: Adrián Bonilla-Petriciolet

Copyright (C) 2021 Aleksandra Ivanovska et al. This is an open access article distributed under the Creative Commons Attribution License, which permits unrestricted use, distribution, and reproduction in any medium, provided the original work is properly cited.

\begin{abstract}
In this investigation, the possibility of wood waste (hardwoods such as oaks' and alternatives' staves from Balkan cooperage) revalorization for simultaneous cadmium removal and wastewater disinfection was examined. All samples were characterized in terms of their crystallinity index and crystallite size, amount of functional groups, and surface chemistry (determined by ATRFTIR) as well as antibacterial activity. Mulberry is characterized by the lowest crystallinity index which can be ascribed to the highest crystallite size disabling crystallite denser packaging, while myrobalan plum has about $23 \%$ lower crystallite size that enables crystallite better packaging, thus resulting in a $42.4 \%$ higher crystallinity index compared to the mulberry. All oaks have a significantly higher amount of carboxyl groups compared to the alternatives (0.23-0.28 vs. 0.12-0.19 mmol/g). The adsorption experiments revealed that with increasing the initial cadmium concentration from 15 up to $55 \mathrm{mg} / \mathrm{g}$, samples' adsorption capacity increases by $89-220 \%$. The equilibrium data fit well with the Langmuir isotherm model implying monolayer coverage of cadmium ions over a homogeneous wood surface. The relationship between the samples' maximum adsorption capacities (ranged from 5.726 to $12.618 \mathrm{mg} / \mathrm{g}$ ), their crystallinity index, and crystallite size was established. According to ATR-FTIR spectra, aldehyde, carboxyl, hydroxyl, and phenyl groups present on the wood waste surface are involved in $\mathrm{Cd}^{2+}$ adsorption which proceeds via the interplay of the complexation, cation- $\pi$ interactions, and ion-exchange mechanisms. Mulberry and myrobalan plum showed about $89 \%$ and $80 \%$ of the total uptake capacity of cadmium within $60 \mathrm{~min}$, while the equilibrium was attained after $240 \mathrm{~min}$ of contact time. Good compliance with pseudo-second kinetic order indicated that cadmium adsorption was mediated by chemical forces. Thermodynamic parameters revealed the spontaneous and exothermic character of cadmium ion adsorption onto mulberry and myrobalan plum. All studied samples provide maximum bacterial reduction (>99\%) for E. coli and S. aureus. Wood waste from Balkan cooperage can be successfully used for simultaneous cadmium removal and wastewater disinfection.
\end{abstract}

\section{Introduction}

From ancient times till nowadays, wood is considered an essential part of humans' daily lives. Among a wide variety of conventional uses, wood also represents an appreciated material for the manufacturing of casks, which are utilized in alcoholic beverage production. Even more, according to
Martínez-Gil et al. [1] and Pecić et al. [2], these wood casks are esteemed as a crucial segment in the production of high-quality wines and aged alcoholic beverages such as brandy, whiskey, and cognac. The Republic of Serbia is classified as a medium forested country with more than 2.6 million ha of forest area; thus, it has a great potential for cooperage development [3]. According to Trade Map data 
[4], in 2019, Serbia exported casks at a value of $712000 \$$, while the growth in casks' exported value was $7 \%$ between the 2015 and 2019 year. In order to satisfy the market demands, the quantity of cut-off old woods constantly increases. Consequently, the loss of the forest area negatively influences all environmental segments of the Earth, including the hydrosphere and the water resources' quality [5].

Moreover, human activities have a strong impact on global and local environmental processes. Namely, industrial modernization along with the domestic activities, agricultural practices, and global changes [6] contributed to the increased generation of large quantities of wastewaters presenting potential threats to entire water resources. Therefore, inadequate wastewater management could cause the contamination of the drinking water for hundreds of millions of people. The presence of heavy metals in wastewater represents a major concern since most of them are highly toxic, carcinogenic, biorecalcitrant, nondegradable, and persistent [7], and they enter our body system through water, food, and air [8]. Among different heavy metals, attention should be given to involuntary human exposure to cadmium which toxic effects were confirmed on many organs' systems [9]. Namely, novel investigations established a connection between the long-term exposure to this toxic metal and various renal syndromes, osteoporosis and osteomalacia, endocrine-disrupting properties, and different types of cancer $[9,10]$. Therefore, the World Health Organization [11] limited the amount of cadmium in drinking water to $0.003 \mathrm{mg} / \mathrm{l}$.

The conventional methods (such as chemical precipitation, membrane filtration, ion exchange, and reverse osmosis) for heavy metal ion removal from wastewaters are ineffective at low heavy metal ions' concentrations (i.e., trace metals); generate a toxic sludge, use high quantities of chemicals, and involve high energy inputs [12]. It has to be noted that the effects of trace metal pollution have not only harmed the plants and crops but also have posed severe health hazards in animals during recent years [13]. Nowadays, adsorption has received remarkable attention since it is very efficient for adsorbing heavy metals present in wastewaters at trace levels, i.e., below $100 \mathrm{mg} / \mathrm{l}$ [14]. Heavy metal removal during wastewater treatment via adsorption is carried out at an interfacial region between the adsorbent and the pollutant [6]. The merits of such type of wastewater treatment compared to the conventional methods are the low formation of chemical and biological sludge, high efficiency, low cost, adsorbents' regeneration, and metal recovery, better selectivity, short processing time, and operating under a broad range of process settings $[13,15,16]$. Recent studies $[12,17,18]$ highlighted wastewater treatment using lignocellulosic materials as effective and environmentally friendly adsorbents.

In the last two decades, the requirements for wood casks at the Balkan were expanded, and therefore, the amount of wood waste generated during cask production considerably increased. This wood waste has a heterogeneous chemical composition including cellulose and noncellulosic components having a high amount of functional groups capable of binding heavy metal ions. One of the possible strategies to revalue such waste is its utilization as an adsorbent for wastewater treatment, which is in agreement with the circular economy concept. Namely, permanent collection and reuse of wood waste have promising multipositive effects on the economy as well environment, including reducing its quantity, saving energy, and its utilization as raw material for profitable innovation.

Besides heavy metals, waterborne diseases contributed to raising awareness about water pollution at the highest level ever. Namely, the consumption of bacteriologically unsafe drinking water is still one of the most significant causes of morbidity and mortality [19], especially in rural areas. Smailagić et al. [20] investigated the antimicrobial activity of eleven wood extracts (oaks, mulberry, myrobalan plum, black locust, and wild cherry) against eight representative human and opportunistic pathogens. The lowest minimum inhibitory concentration (MIC) was observed against $S$. aureus for black locust, cherry, and mulberry wood extracts, and based on the conducted research, the usefulness of such wood waste for water disinfection is expected.

In this investigation, the possibility to revalue the wood waste (i.e., hardwoods such as oaks' and alternatives' staves) from Balkan cooperage will be examined. For that purpose, cadmium ion was chosen as a model ion to test the ability of wood waste for heavy metal removal from an aqueous solution. In this study, for the first time, the connection between the wood waste molecular and fine structure (i.e., the presence and amount of $\mathrm{COOH}$ and $\mathrm{CHO}$ groups as well as crystallinity index and crystallite size) and its adsorption potential for $\mathrm{Cd}^{2+}$ removal from aqueous solution was established. Moreover, the wood waste antibacterial activity was tested against Gram-negative bacteria E. coli and Grampositive bacteria $S$. aureus to study the possibility of simultaneous cadmium removal and wastewater disinfection.

\section{Materials and Methods}

2.1. Material. In this experiment, six wood waste samples of different botanical species and geographical origins (see Table 1) obtained from a local cask producer (VBX-SRL. D.O.O. Kraljevo, Serbia) were used as adsorbents for cadmium ions from an aqueous solution. Before the experiments, the wood samples were ground in a mill for wood, whereby their particle size was in the range of $0.5-1.5 \mathrm{~mm}$.

2.2. X-Ray Diffraction Analysis. The X-ray measurements were performed on a Rigaku Ultima IV diffractometer in a Bragg-Brentano configuration using $\mathrm{CuK} \alpha$ radiation. The diffraction data were acquired over the $2 \theta$ scattering angle (from $10^{\circ}$ to $40^{\circ}$ ) with a step of $0.05^{\circ}$ and an acquisition time of $2 \% \mathrm{~min}$. The obtained X-ray diffraction patterns were resolved into proportions of cellulose $\mathrm{I}_{\beta}$ lattice (characteristic peaks are located at $2 \theta$ of $14.7^{\circ}, 16.8^{\circ}$, and $22.7^{\circ}$ corresponding to the reflections (1-10), (110), and (200), respectively [21]), and amorphous region using the Gaussian and Lorentzian distribution function. The conventional peak deconvolution involved curve fitting (by using a commercial software Peakfit v4.12) to the observed pattern with the individual visible peaks plus a very broad peak for the amorphous 
TABLE 1: Wood waste samples' codes, botanical species, geographical origin, age, and soil type.

\begin{tabular}{lccrc}
\hline Sample code & Tree & Geographical origin & Wood age, years & Soil type \\
\hline BL & Black locust-Robinia pseudoacacia L. & Kraljevo (Serbia) & $>40$ & Fluvisolo \\
M & Mulberry-Morus alba L. & Vrnjačka Banja (Serbia) & $>40$ & Vertisol \\
MP & Myrobalan plum-Prunus cerasifera Ehrh & Vrnjačka Banja (Serbia) & $>40$ & Vertisol \\
SORG & Sessile oak-Quercus petraea (Matt.) L. & Ravna Gora (Serbia) & $>60$ & Rankers \\
POGR & Pedunculate oak-Quercus robur L. & Gornji Radan (Serbia) & $>60$ & Rankers \\
POBO & & Olovo (Bosnia and Herzegovina) & $>60$ & Rankers \\
\hline
\end{tabular}

material. The wood waste crystallinity index (CrI) was calculated from the ratio of the area of all crystalline peaks to the total area, while the crystallite size $\tau(\mathrm{nm})$ perpendicular to the lattice plane-the (200) plane was calculated by the Sherrer equation [22]. Reported crystallinity index and crystallite size values are the average values of three parallel measurements, whereby the coefficients of variation were below $0.8 \%$.

2.3. Determination of the Amount of Carboxyl and Aldehyde Groups. The amount of carboxyl and aldehyde groups was determined by a calcium-acetate method. A sample $(0.5 \mathrm{~g})$ was treated with $100 \mathrm{ml} 0.01 \mathrm{M} \mathrm{HCl}$ solution for $1 \mathrm{~h}$ following by washing with distilled water. In the next step, $50 \mathrm{ml}$ distilled water and $30 \mathrm{ml} 0.25 \mathrm{M} \mathrm{CH}_{3} \mathrm{COOCa}$ solution were added, and the mixture was stirred for $2 \mathrm{~h}$. Thereafter, $30 \mathrm{ml}$ portions of the liquid were titrated with $0.01 \mathrm{M} \mathrm{NaOH}$ solution, using phenolphthalein as an indicator. The amount of carboxyl groups is calculated as follows, Eq. (1):

$$
\mathrm{COOH}=\frac{80 / 30 \bullet 0.01 \mathrm{M} \bullet V(\mathrm{NaOH})}{m}\left[\frac{\mathrm{mmol}}{\mathrm{g}} \text { waste wood }\right],
$$

where $0.01 \mathrm{M}$ is a concentration of $\mathrm{NaOH}, \mathrm{V}(\mathrm{NaOH})$ is the volume of $\mathrm{NaOH}$ solution used for titration $(\mathrm{ml})$, and $m$ is the weight of an absolutely dry wood waste sample (g).

The amount of aldehyde groups was determined according to the method described by Saito and Isogai [23]. In order to selectively oxidize the sample's aldehyde groups to carboxyl groups, $1 \mathrm{~g}$ of a sample was added to a mixture containing $0.905 \mathrm{~g} \mathrm{NaClO}_{2}, 10 \mathrm{ml} 5 \mathrm{M} \mathrm{CH}_{3} \mathrm{COOH}$ solution, and $50 \mathrm{ml}$ distilled water. Oxidation was carried out by mixture stirring at room temperature for $48 \mathrm{~h}$, and thereafter, the sample was thoroughly washed with distilled water and acetone. Further, the previously described calcium acetate method for determining the amount of carboxyl groups was applied. The amount of aldehyde groups was calculated by subtracting the amount of carboxyl groups determined in the starting sample from that of chlorite oxidized one. The average of four measurements for each sample was considered, and the obtained coefficients of variation were below $1.2 \%$.

2.4. Adsorption Experiments. The adsorption of cadmium ions was carried out from freshly prepared $\mathrm{CdCl}_{2} \cdot 2.5 \mathrm{H}_{2} \mathrm{O}$, whereby the wood waste samples $(0.5 \mathrm{~g})$ were immersed each in $200 \mathrm{ml}$ of a cadmium chloride solution and constantly shaken. In the first step of adsorption experiments' optimiza- tion, the effect of initial solution $\mathrm{pH}$ on the $\mathrm{Cd}^{2+}$ adsorption onto wood waste was examined, whereas the solution $\mathrm{pH}$ was adjusted to the values of 3-6 by stepwise addition of $\mathrm{HNO}_{3}$ or $\mathrm{NH}_{4} \mathrm{OH}$. The $\mathrm{pH}$ value of 5.50 was used for all adsorption experiments. In further steps of adsorption optimization, the cadmium initial concentration was varied in the range of $15-55 \mathrm{mg} / \mathrm{l}$, and the contact time was varied in the range of 5-1440 min, while the temperature was varied in the range of $25-45^{\circ} \mathrm{C}$. The cadmium concentration in an aqueous solution was determined using the analytical technique of inductively coupled plasma optical emission spectrometry (ICP-OES, iCAP 6500 Duo ICP, Thermo Fisher Scientific, Cambridge, United Kingdom). The MultiElement plasma standard solution 4, Specpure ${ }^{\circledR}, 1000 \mu \mathrm{g} / \mathrm{ml}$ (Alfa Aesar GmbH \& Co KG, Germany) was used to prepare a calibration solution for ICP-OES measurement. The measurements were performed at Cd II $226.502 \mathrm{~nm}$ emission line. Quality control was carried out using blank samples, matrix-matched calibration solutions, and triplicate analyses of each sample. The reliability of measurements was approved by a relative standard deviation (RSD) $<0.5 \%$.

The cadmium adsorption $(q)$ was determined according to Eq. (2):

$$
q(\mathrm{mg} / \mathrm{g})=\frac{c_{0}-c_{t}}{m} \cdot V
$$

where $c_{0}$ is the initial cadmium concentration in solution $(\mathrm{mg} / \mathrm{l}) ; c_{t}$ is the cadmium concentration in the solution after a defined period ( $\mathrm{mg} / \mathrm{l}) ; V$ is solution volume (l), and $m$ is the mass of a dry wood sample (g).

Langmuir and Freundlich isotherm models (Table 2) were used to fit the isotherm experimental data and further to assess the wood waste adsorption capacity toward cadmium ions. On the other hand, the pseudo-first and pseudo-second-order kinetic models (Table 3 ) were used to investigate the cadmium adsorption mechanism on selected wood waste. OriginPro 2015 was used as a tool for kinetic and isotherm non-linear estimation.

The adsorption experiments performed at different temperatures allow calculation of the thermodynamic parameters such as standard Gibbs free energy $\left(\Delta \mathrm{G}^{\circ}\right)$, standard enthalpy $\left(\Delta \mathrm{H}^{\circ}\right)$, and standard entropy $\left(\Delta \mathrm{S}^{\circ}\right)$ by using Eqs. (3) and (4).

$$
\begin{aligned}
& \Delta G^{\circ}=-R \cdot T \cdot \ln \left(K_{\mathrm{eq}}\right), \\
& \Delta G^{\circ}=\Delta H^{\circ}-T \cdot \Delta S^{\circ},
\end{aligned}
$$


TABLE 2: Langmuir and Freundlich isotherm models' equations and obtained isotherm parameters for cadmium adsorption on wood waste.

\begin{tabular}{|c|c|c|c|c|c|c|}
\hline \multicolumn{7}{|c|}{ Adsorption isotherms } \\
\hline \multirow[t]{2}{*}{ Sample code } & \multicolumn{4}{|c|}{ Isotherm parameters } & \multicolumn{2}{|c|}{$\begin{array}{l}\text { Freundlich } \\
q_{e}=K_{f} C_{e}^{\frac{1}{n}}\end{array}$} \\
\hline & $K_{L}$ & $q_{m}$ & $R^{2}$ & $K_{f}$ & $n$ & $R^{2}$ \\
\hline $\mathrm{BL}$ & 0.103 & 11.644 & 0.997 & 2.348 & 2.556 & 0.965 \\
\hline M & 0.491 & 12.618 & 0.975 & 5.805 & 4.370 & 0.930 \\
\hline MP & 0.049 & 5.726 & 0.993 & 0.694 & 2.164 & 0.973 \\
\hline SORG & 0.257 & 10.723 & 0.964 & 3.802 & 3.568 & 0.985 \\
\hline POGR & 0.047 & 7.571 & 0.997 & 0.820 & 2.038 & 0.982 \\
\hline POBO & 0.159 & 9.170 & 0.979 & 2.684 & 3.254 & 0.967 \\
\hline
\end{tabular}

In equations given in Table $2, q_{e}=q_{e, \text { exp }}(\mathrm{mg} / \mathrm{g})$ is the equilibrium cadmium concentration per gram adsorbent, and $q_{m}(\mathrm{mg} / \mathrm{g})$ is a maximal adsorbed cadmium per gram adsorbent; $K_{L}(\mathrm{l} / \mathrm{mg})$ is the Langmuir constant. $C_{e}(\mathrm{mg} / \mathrm{l})$ is the equilibrium cadmium concentration in the solution, $K_{f}$ is the Freundlich constant $(\mathrm{mg} / \mathrm{g}) /(\mathrm{l} / \mathrm{mg}) 1 / n$, and $n$ is constant related to the wood surface heterogeneity.

TABLE 3: Kinetic models' equations and kinetic parameters obtained by the pseudo-first and pseudo-second-order kinetic models for Cd ${ }^{2+}$ ions $\left(c_{0}=55 \mathrm{mg} / \mathrm{l}\right)$ adsorption on waste wood samples.

\begin{tabular}{|c|c|c|c|c|c|}
\hline \multirow{3}{*}{ Sample code } & \multicolumn{4}{|c|}{ Kinetic models } & \multirow{3}{*}{$q_{e}, \exp$} \\
\hline & \multicolumn{2}{|c|}{$\begin{array}{l}\text { Pseudofirst kinetic model } \\
\qquad q_{t}=q_{e} \bullet\left(1-e^{-k_{1} \bullet t}\right)\end{array}$} & \multicolumn{2}{|c|}{$\begin{array}{l}\text { Pseudosecond kinetic model } \\
\qquad q_{t}=q_{e}-\left(\frac{1}{q_{e}}+k_{2} \bullet t\right)^{-1}\end{array}$} & \\
\hline & $q_{e, \mathrm{cal}}$ & $k_{1}$ & $q_{e, \mathrm{cal}}$ & $k_{2}$ & \\
\hline $\mathrm{M}$ & 11.608 & 0.069 & 12.450 & 0.008 & 11.921 \\
\hline MP & 3.673 & 0.087 & 3.920 & 0.032 & 3.994 \\
\hline
\end{tabular}

In equations given in Table $3, q_{e}=q_{e, \text { exp }}$ and $q_{t}(\mathrm{mg} / \mathrm{g})$ are the amounts of cadmium ions adsorbed per gram adsorbent at equilibrium and at time $t$ (min); $k_{1}$ $(1 / \mathrm{min})$ is a pseudofirst-order rate constant, and $k_{2}(\mathrm{~g} / \mathrm{mg} \mathrm{min})$ is a pseudo-second-order rate constant.

where $R$ is the universal gas constant $(8.314 \mathrm{~J} / \mathrm{mol} \mathrm{K}), T$ is the temperature of the process $(K), K_{\mathrm{eq}}$ is the process equilibrium constant calculated as the ratio between the amount of cadmium adsorbed $q_{e}(\mathrm{mg} / \mathrm{g})$, and the residual cadmium concentration in the solution $C_{e}(\mathrm{mg} / \mathrm{ml})$ at the equilibrium (Eq. (5)).

$$
K_{\mathrm{eq}}=\frac{q_{e}}{C_{e}}
$$

The expression of the equilibrium constant quantifies the distribution of the pollutant between the solution and the adsorbed phase. By combining Eqs. (3) and (4), the following Eq. (6) is obtained:

$$
\ln \left(K_{\mathrm{eq}}\right)=-\frac{\Delta H^{\circ}}{R T}+\frac{\Delta S^{\circ}}{R} .
$$

The $K_{\text {eq }}$ and $\Delta \mathrm{G}^{\circ}$ were calculated for each studied temperature, while the values of $\Delta H^{\circ}$ and $\Delta S^{\circ}$ were estimated from the slopes and intercepts of $\ln \left(K_{\mathrm{eq}}\right)$ vs. 1/ $T$ plot, respectively.

All adsorption experiments were conducted in triplicate whereas the coefficients of variation were below $3.1 \%$.
In order to analyze the effect of cosolutes on the $\mathrm{Cd}^{2+}$ adsorption onto mulberry (sample $\mathrm{M}$ ), two real matrixes (i.e., tap water and water from River Sava, Belgrade, Republic of Serbia) were prepared by adding $55 \mathrm{mg} / \mathrm{l}$ cadmium, with and without $\mathrm{pH}$ adjustment. Tap and river waters were collected on June 17, 2021. According to the analysis performed by the Institute of Public Health Belgrade, Republic of Serbia, the tap water parameters were $\mathrm{pH} 7.71,198 \mathrm{mg} / \mathrm{l} \mathrm{HCO}_{3}{ }^{-}, 36.73 \mathrm{mg} / \mathrm{l}$ $\mathrm{NO}_{3}{ }^{-}, 0.005 \mathrm{mg} / \mathrm{l} \mathrm{NO}_{2}^{-}, 62.12 \mathrm{mg} / \mathrm{l} \mathrm{Ca}^{2+}, 14.36 \mathrm{mg} / \mathrm{l} \mathrm{Mg}^{2+}, 8,64$ $\mathrm{mg} / \mathrm{l} \mathrm{Na}{ }^{+}$, and $1.85 \mathrm{mg} / \mathrm{K}^{+}$. The Sava river water parameters were $\mathrm{pH} 7.78,210 \mathrm{mg} / \mathrm{l} \mathrm{HCO}_{3}^{-}, 1.2 \mathrm{mg} / \mathrm{l} \mathrm{NO}_{3}^{-}, 0.006 \mathrm{mg} / \mathrm{l}$ $\mathrm{NO}_{2}{ }^{-}, 49 \mathrm{mg} / \mathrm{l} \mathrm{Ca}^{2+}, 12 \mathrm{mg} / \mathrm{l} \mathrm{Mg}^{2+}$, and $0.0033 \mathrm{mg} / \mathrm{l} \mathrm{Cd}^{2+}$.

2.5. ATR-FTIR Analysis. Attenuated total reflectance Fourier transform infrared spectroscopy (ATR-FTIR) was employed to identify the wood waste surface functional groups capable of binding cadmium ions. The transmission spectra were obtained using a Shimadzu IR-Affinity spectrophotometer equipped with an attenuated total reflectance accessory (ATR) using a diamond/ZnSe crystal in the wavenumber range of $4000-600 \mathrm{~cm}^{-1}$, at a resolution of $4 \mathrm{~cm}^{-1}$.

2.6. Antibacterial Activity of Wood Waste Samples. The wood waste samples' antibacterial activity was determined against Gram-negative bacteria E. coli ATCC 25922 and Grampositive bacteria S. aureus ATCC 25923 using a standard test 
method (ASTM E 2149-01 (2001)). The microbial reduction $(R)$ was calculated according to Eq. (7):

$$
R(\%)=\frac{C_{0}-C}{C_{0}} \cdot 100,
$$

where $C_{0}$ colony-forming units is the number of microbe colonies in the control, and $C$ is the number of microbe colonies on the wood waste sample $(\mathrm{CFU} / \mathrm{ml})$. The results are given as the mean value of two measurements per sample, while the coefficients of variation are below $5 \%$.

\section{Results and Discussion}

3.1. Characterization of Adsorbents. It is well known that the adsorption of heavy metal ions onto lignocellulosic materials depends on adsorption conditions such as contact time, initial ion concentration, temperature, solution $\mathrm{pH}$, adsorbent dosage, and particle size, etc. However, adsorption strongly depends on the adsorbent itself. In order to get insight into the adsorption process and to describe the different adsorption capacities of samples belonging to the same class of hardwoods (i.e., alternatives or oaks), a detailed adsorbents' characterization is required.

First, the crystallinity index and crystallite size (see Figure 1) were determined concerning the fact that the amorphous regions are responsible for wood waste sorption properties, i.e., enable easier penetration of a higher amount of water molecules into a wood structure contributing to better sorption properties [24] including adsorption of heavy metal ions from an aqueous solution. More precisely, through adsorption and absorption onto/into the amorphous regions, the aqueous solution comes into contact with a very large surface area of different cell wall components having a high amount of functional groups capable of binding cadmium ions.

From Figure 1, it is evident that the crystallinity index is independent of the hardwood class (i.e., alternatives and oaks). However, there is a correlation between the crystallinity index and crystallite size. For example, mulberry (sample $\mathrm{M})$ is characterized by the lowest crystallinity index $(\mathrm{CrI}=0.561)$ which can be ascribed to the highest crystallite size $(\tau=2.939 \mathrm{~nm})$ disabling crystallite denser packaging. In contrast, myrobalan plum (sample MP) has about $23 \%$ lower crystallite size $(\tau=2.254 \mathrm{~nm})$ that enables crystallite better packaging thus resulting in a $42.4 \%$ higher crystallinity index $(\mathrm{CrI}=0.799)$ compared to the mulberry.

Besides crystallinity index and crystallite size, the content of carboxyl (primarily present in hemicelluloses, pectin, and lignin) and aldehyde (present in lignin) groups was determined since they represent active sites for binding heavy metal ions [25]. The results listed in Table 4 revealed that all oaks (samples SORG, POGR, and POBO) have a significantly higher amount of carboxyl groups compared to the alternatives (samples BL, M, and MP). According to Alañón et al. [26] and Rowell et al. [27], such results can be explained by a higher content of hydrolyzable tannins present in the oaks, which is also in agreement with our previously published data [28]. Namely, the total content of ellagic and gallic acid (representing hydrolyzable tannins' derivates) in the oaks' extracts ranged from 3057 to $9416 \mathrm{mg} / \mathrm{kg}$, while their content in the alternatives' extracts ranged from 376 to $1190 \mathrm{mg} / \mathrm{kg}$.

On the other hand, phloretin was detected in the myrobalan plum and mulberry (samples MP and M) extracts [28], where aldehyde groups are present. The absence of this compound in the oaks' extracts might be a possible reason for the lower amount of aldehyde groups in SORG and POBO, than in the alternatives, Table 4.

3.2. Adsorption of Cadmium Ions by Wood Waste. Cadmium was chosen as a model ion to test the ability of wood waste for heavy metal ion removal from an aqueous solution. In further text, the connection between different experimental variables (i.e., initial solution $\mathrm{pH}$, initial ion concentration, contact time, and temperature), wood waste structure, and adsorption capacity will be discussed in detail.

\subsection{Effect of Initial Solution $p H$ on the Cadmium Adsorption} onto Wood Waste. Taking into consideration the fact that the initial solution $\mathrm{pH}$ affects the solubility and ionization state of investigated $\mathrm{Cd}^{2+}$ salt, as well as the wood waste surface charge, preliminary experiments by varying the $\mathrm{pH}$ value (from 3.0 up to 6.0) were conducted to determine the solution $\mathrm{pH}$ at which the cadmium adsorption is the highest, Figure 2.

The presented results revealed that at the lowest studied solution $\mathrm{pH}$ (i.e., 3.0), the wood waste samples' affinity for binding $\mathrm{Cd}^{2+}$ is low, especially in the case of samples MP and POGR. This behavior is ascribed to the presence of a high concentration of $\mathrm{H}^{+}$, whereby the dissociation of $\mathrm{COOH}$ groups is suppressed, and the competition and repulsion between $\mathrm{H}^{+}$and $\mathrm{Cd}^{2+}$ for the wood waste active sites appeared, altogether resulting in less negative wood waste surface [29]. With further increasing the solution $\mathrm{pH}$ up to 5.50 , the $\mathrm{Cd}^{2+}$ adsorption increases which could be explained by the parallel influence of functional groups' ionization and the increased negative charge density at the wood waste surface contributing to the increased attraction of the $\mathrm{Cd}^{2+}$. At a solution $\mathrm{pH}$ of 5.50 , the highest $\mathrm{Cd}^{2+}$ adsorption was registered for all studied wood waste samples, while above this $\mathrm{pH}$, the adsorption started to decrease due to the higher concentration of the $\mathrm{OH}$ in the solution. In order to achieve maximum $\mathrm{Cd}^{2+}$ adsorption, the $\mathrm{pH}$ of 5.50 was chosen for further experiments.

3.4. Adsorption Isotherms. The effect of initial cadmium concentration on wood waste equilibrium adsorption (in further text: $q_{e}$ ) is given in Figure 3. As was expected, with increasing the initial ion concentration from 15 up to $55 \mathrm{mg} / \mathrm{l}$, the samples' $q_{e}$ increases. In other words, the driving force for cadmium ions' adsorption is the gradient of concentration between the aqueous phase and the solid one, which overcomes the resistance to mass transfer between the two phases; the higher the gradient, the more favored the process [30]. The most prominent increase (about 2.2 times) in the $q_{e}$ was observed for the sample POGR, while the lowest increase (about 89\%) in $q_{e}$ was 


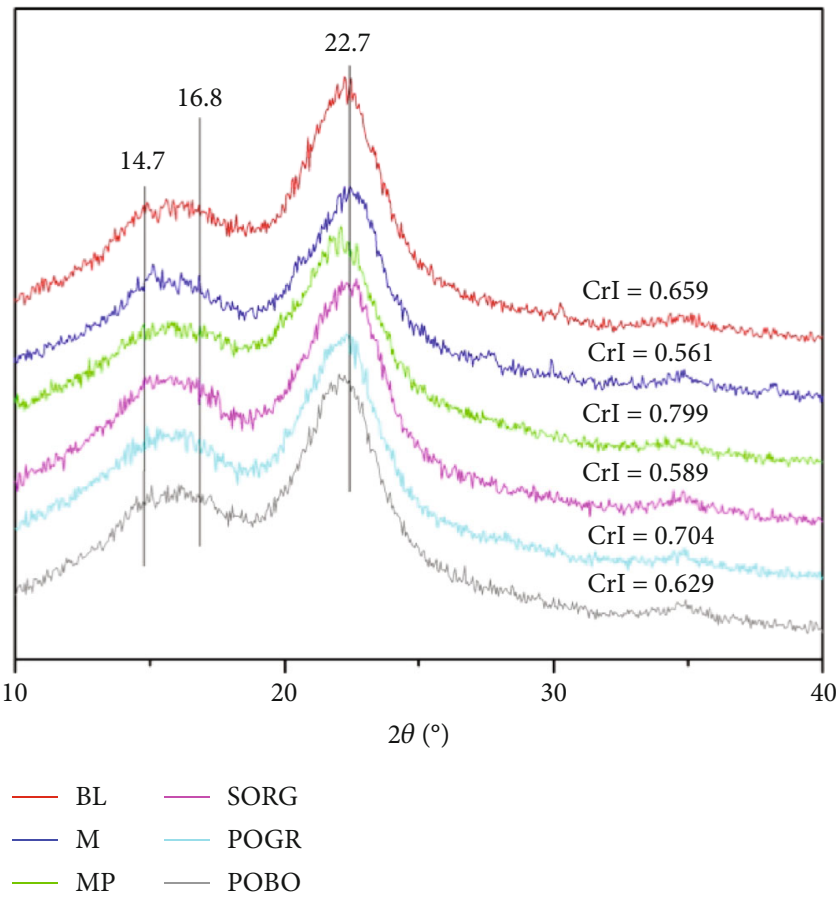

(a)

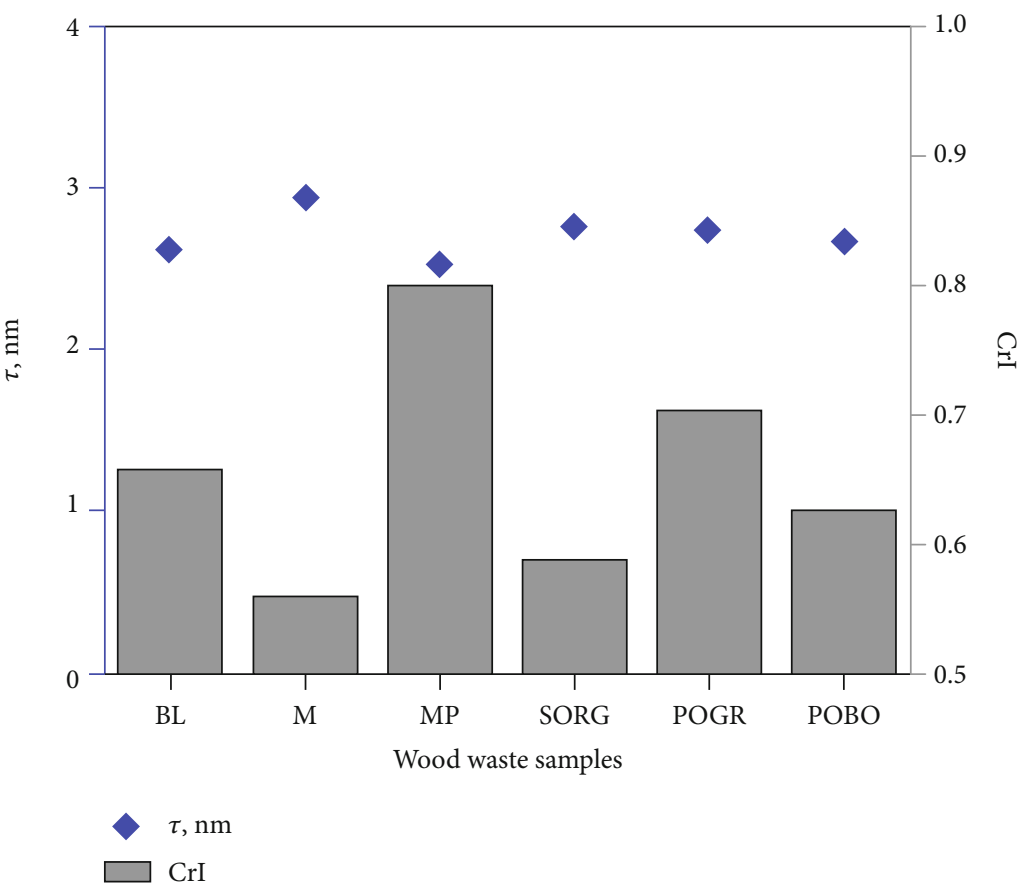

(b)

FIGURE 1: (a) X-ray diffraction patterns and crystallinity index (CrI). (b) Relationship between crystallinity index (CrI) and crystallite size $(\tau)$.

observed for the sample POBO. It is worth mentioning that the same trend $(\mathrm{M}>\mathrm{SORG}>\mathrm{BL}>\mathrm{POBO}>\mathrm{POGR}>\mathrm{MP})$ for $q_{e}$ was evident for all initial cadmium concentrations, Figure 3.

The interaction between cadmium ions and wood waste samples can be easily described by treating the equilibrium data (see Figure 3) according to Langmuir and Freundlich adsorption equations (see Table 2). The adsorption isotherms' plots and the nonlinear fit of the experimental data are presented in Figure 4, while the coefficients of determination $\left(R^{2}\right)$ are listed in Table 2. Somewhat higher values of the coefficient of determination were obtained using the Langmuir $\left(R^{2}=0.964-0.997\right)$ than Freundlich $\left(R^{2}=0.930-\right.$ 0.985 ) model (with the exception of sample SORG), pointing 
TABle 4: Amount of carboxyl $(\mathrm{COOH})$ and aldehyde (CHO) groups.

\begin{tabular}{lccc}
\hline Sample code & $\begin{array}{c}\mathrm{COOH} \\
{[\mathrm{mmol} / \mathrm{g}]}\end{array}$ & $\begin{array}{c}\mathrm{CHO} \\
{[\mathrm{mmol} / \mathrm{g}]}\end{array}$ & $\begin{array}{c}\mathrm{COOH}+\mathrm{CHO} \\
{[\mathrm{mmol} / \mathrm{g}]}\end{array}$ \\
\hline $\mathrm{BL}$ & 0.1222 & 0.4129 & 0.5351 \\
$\mathrm{M}$ & 0.1884 & 0.4167 & 0.6051 \\
MP & 0.1320 & 0.3673 & 0.4993 \\
SORG & 0.2793 & 0.3173 & 0.5966 \\
POGR & 0.2325 & 0.3504 & 0.5829 \\
POBO & 0.2455 & 0.2258 & 0.4173 \\
\hline
\end{tabular}

out that it could be more suitable for describing the system under study. According to Park et al. [31] and Khan et al. [32], better fitting with the Langmuir isotherm model implies monolayer coverage of cadmium ions over a homogeneous wood waste surface.

The isotherm parameters determined by fitting the experimental data (see Figure 3) with the Langmuir and Freundlich adsorption equations are given in Table 2. The maximal wood waste samples' adsorption capacity $\left(q_{m}\right)$, derived from Langmuir modeling is in the range from 5.726 to $12.618 \mathrm{mg} / \mathrm{g}$. Observing in parallel the results obtained for samples' $q_{m}$ and crystallinity index (see Table 2 and Figures 1(b) and 1(a)), good linear correlation $\left(r^{2}=-0.889\right)$ between them was found. Namely, the highest $q_{m}$ of mulberry (sample $\mathrm{M}$ ) is conditioned by its highest amount of amorphous regions (i.e., lower crystallinity index) as well as the highest crystallite size. Additionally, the highest value of the Langmuir constant $\left(K_{L}=0.491 \mathrm{l} / \mathrm{mg}\right.$, Table 2$)$ was observed for this sample indicating a strong interaction between mulberry and cadmium ions. A considerable influence of the mentioned factors on $q_{m}$ is also proved for other wood waste samples. Opposite from mulberry, myrobalan plum's crystallites are better packaged (i.e., a sample has a higher crystallinity index) representing some kind of barrier which obstructs the diffusion of cadmium ions within the sample and consequently their adsorption. Even more, this sample possesses a weak interaction with cadmium ions $\left(K_{L}=0.049\right.$, Table 2$)$.

Taking into account the results obtained for the alternatives' $q_{m}$ (see Table 2) and the total amount of $\mathrm{COOH}$ and CHO groups (see Table 4), it is evident that the $q_{m}$ is also conditioned by the total amount of $\mathrm{COOH}$ and $\mathrm{CHO}$ groups (linear correlation $r^{2}=0.838$ ). However, in the case of the oaks, the situation is different. Namely, besides the crystallinity index and crystallite size, $q_{m}$ depends on the amount of $\mathrm{COOH}$ groups $\left(r^{2}=0.966\right)$. All mentioned indicates that governing removal $\mathrm{Cd}^{2+}$ mechanism proceeds via carboxyl groups, which is additionally confirmed by ATR-FTIR spectroscopy.

The ATR-FTIR spectra of wood waste samples' that possess the highest and the lowest adsorption potential (samples $\mathrm{M}$ and MP, respectively) as well as the sample SORG which belongs to the class of oaks were recorded before and after cadmium adsorption, Figure 5. As it was expected, after the adsorption, the wood waste samples' surface chemistry chan-

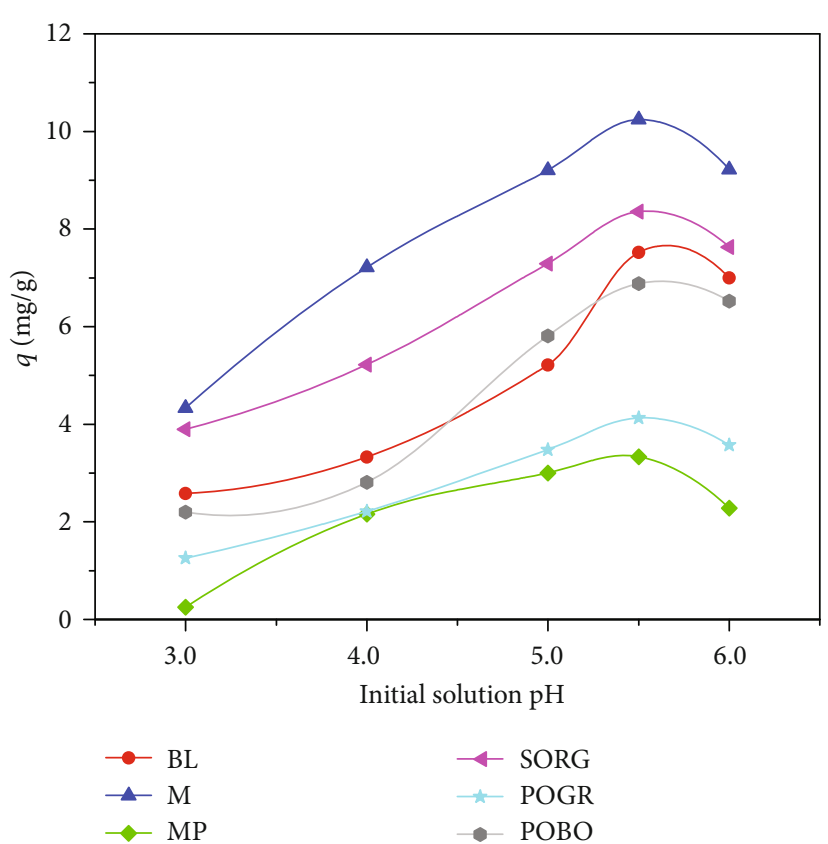

FIgURE 2: The influence of initial solution $\mathrm{pH}$ on the cadmium adsorption $(q)$ onto wood waste.

ged, i.e., the reduction of the certain peaks' intensities was observed. The intensity of the peak at $1735 \mathrm{~cm}^{-1}$ (corresponding to $\mathrm{C}=\mathrm{O}$ stretching vibration of carboxyl acid or ester groups in hemicelluloses [33]) decreases, pointing out that the carboxyl groups play an important role in the cadmium adsorption process. Lower intensities of the peaks at $1505 \mathrm{~cm}^{-1}$ and $1460 \mathrm{~cm}^{-1}$ (aromatic ring $\mathrm{C}=\mathrm{C}$ of the lignin phenylpropane group [33]), $1596 \mathrm{~cm}^{-1}$ (aromatic skeletal vibrations and ring breathing with $\mathrm{C}-\mathrm{O}$ stretching in lignin [34]), $824 \mathrm{~cm}^{-1}$ (C-H vibration of aromatic compounds), and at $1232 \mathrm{~cm}^{-1}$ and $1315 \mathrm{~cm}^{-1}$ (ring breathing of guaiacyl "G" and syringyl "S," respectively [35]) observed after the adsorption indicate cation- $\pi$ interactions between the cadmium ions and mentioned functional groups located on the wood waste surface. Furthermore, after the adsorption, the peak at $3329 \mathrm{~cm}^{-1}$ assigned to $\mathrm{O}-\mathrm{H}$ stretching vibrations of hydroxyl and carboxyl groups [36] was broadened and has lower intensity confirming that the hydroxyl groups also participate in the cadmium adsorption through the formation of ion-dipole interactions. Lastly, decreased intensity of the peak with maxima at $2910 \mathrm{~cm}^{-1}$ (functional groups of methyl, methylene, and aliphatic saturated hydrocarbons of lignin as well as polysaccharides) after the adsorption is most probably a consequence of cadmium binding.

Taking into account the fact that the cadmium removal mechanism is complex and dependent on various factors such as the wood's nature and its surface chemistry and heterogeneity, some general remarks on the interactions between wood surface functional groups and $\mathrm{Cd}^{2+}$ could be made. Having in mind that the adsorption trend of different wood waste samples do not correlate very well with the total amount of aldehyde and carboxyl groups $\left(r^{2}=0.838\right)$, it is justified to assume that besides these groups, some other 


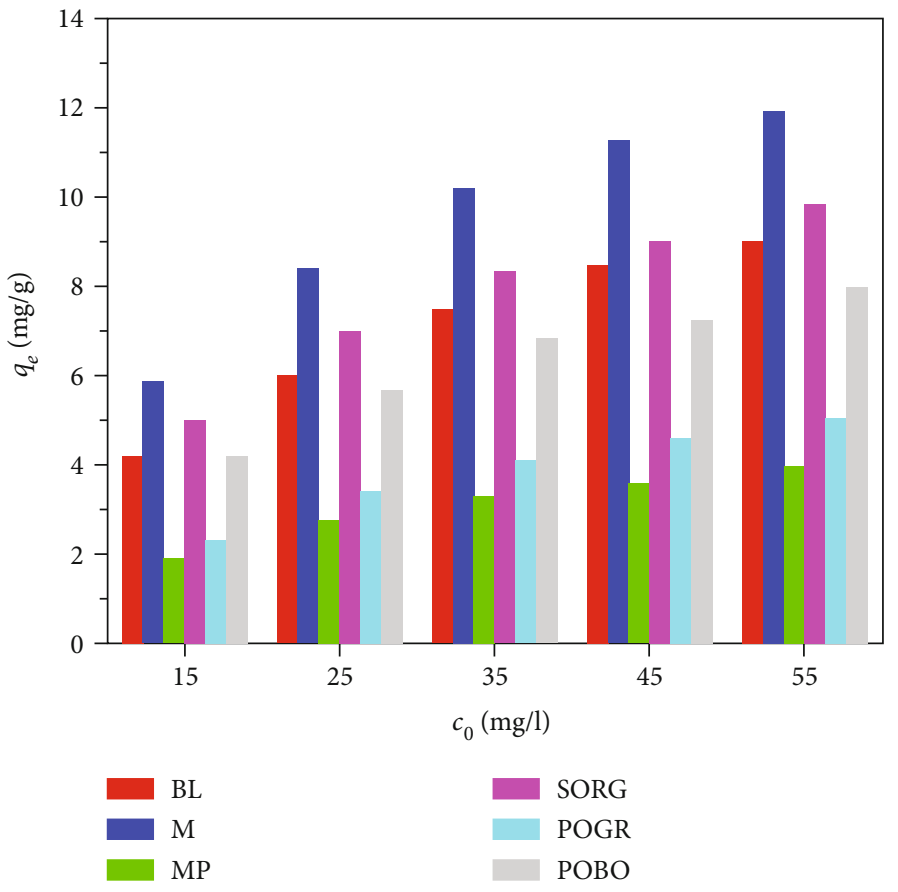

FIGURE 3: Equilibrium cadmium adsorption $\left(q_{e}\right)$ as a function of its initial concentration $\left(c_{0}\right)$.

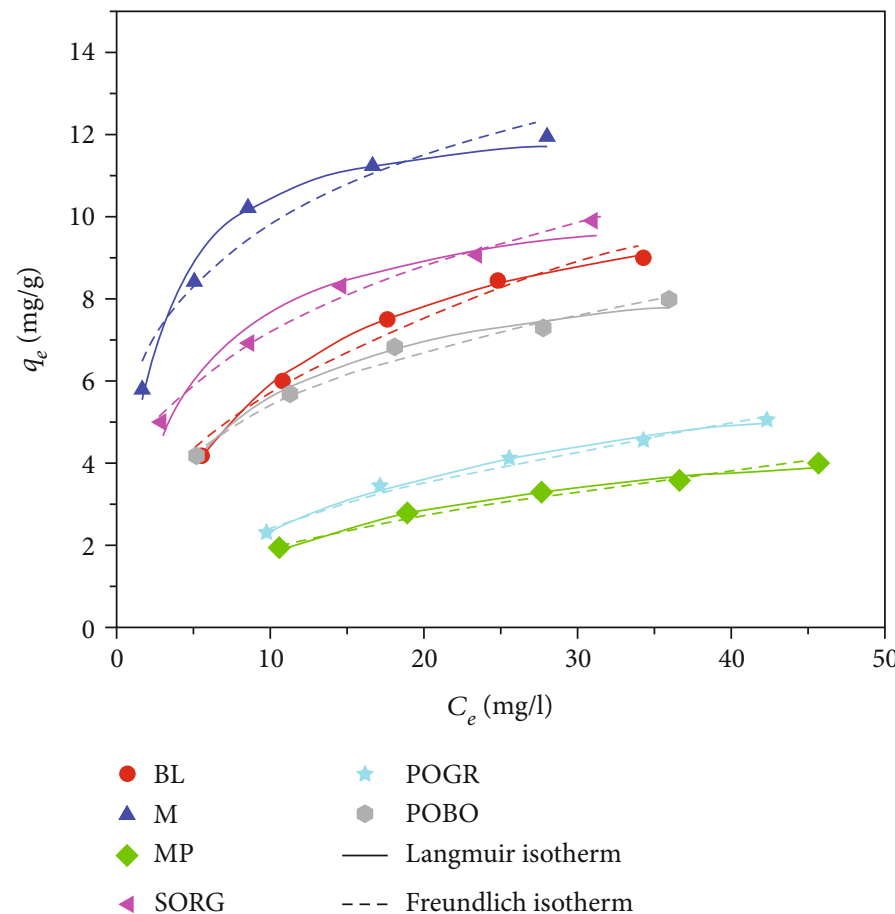

FIGURE 4: Adsorption isotherms and nonlinear fit of experimental adsorption data for $\mathrm{Cd}^{2+}$.

groups present on the wood waste surface, such as hydroxyl and phenyl (originating from lignin and tannins), also play an important role in $\mathrm{Cd}^{2+}$ binding mechanism. Namely, according to ATR-FTIR spectra, it is evident that all aforementioned functional groups are involved in $\mathrm{Cd}^{2+}$ adsorption which proceeds via the interplay of the complexation, cation- $\pi$ interactions, and ion-exchange mechanisms (Figure 6). Carboxyl and hydroxyl groups may be involved in two different mechanisms: ion exchange (occurs between $\mathrm{Cd}^{2+}$ and $\mathrm{H}^{+}$) and surface complexation [37], while electron-rich phenyl groups participate in the cation- $\pi$ interactions [38, 39]. Electrostatic interactions between 


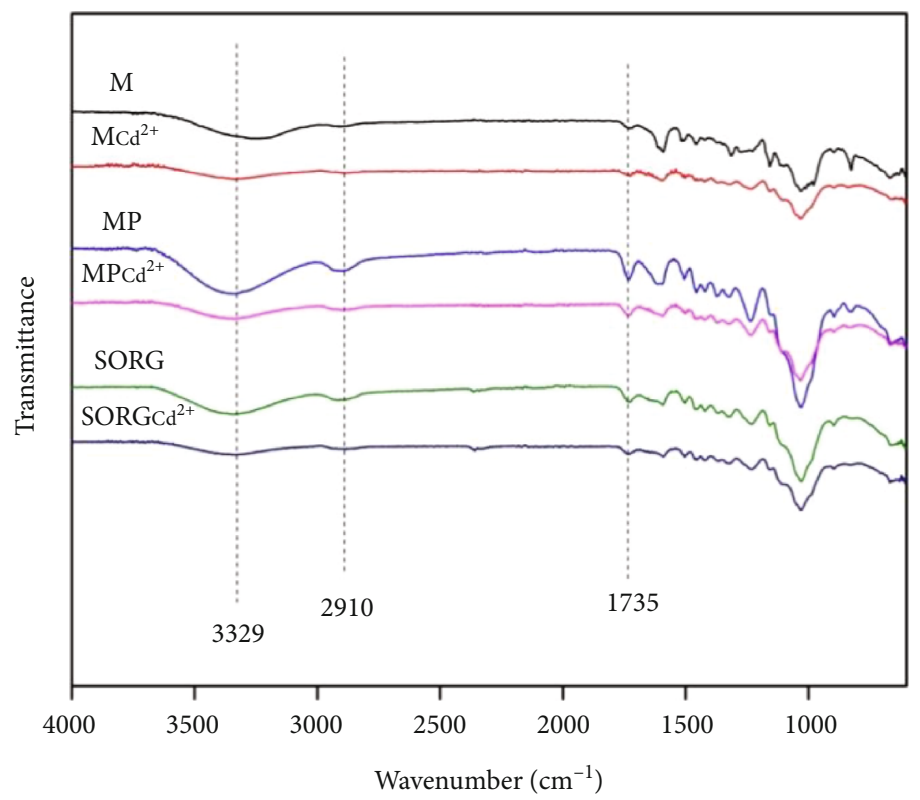

(a)

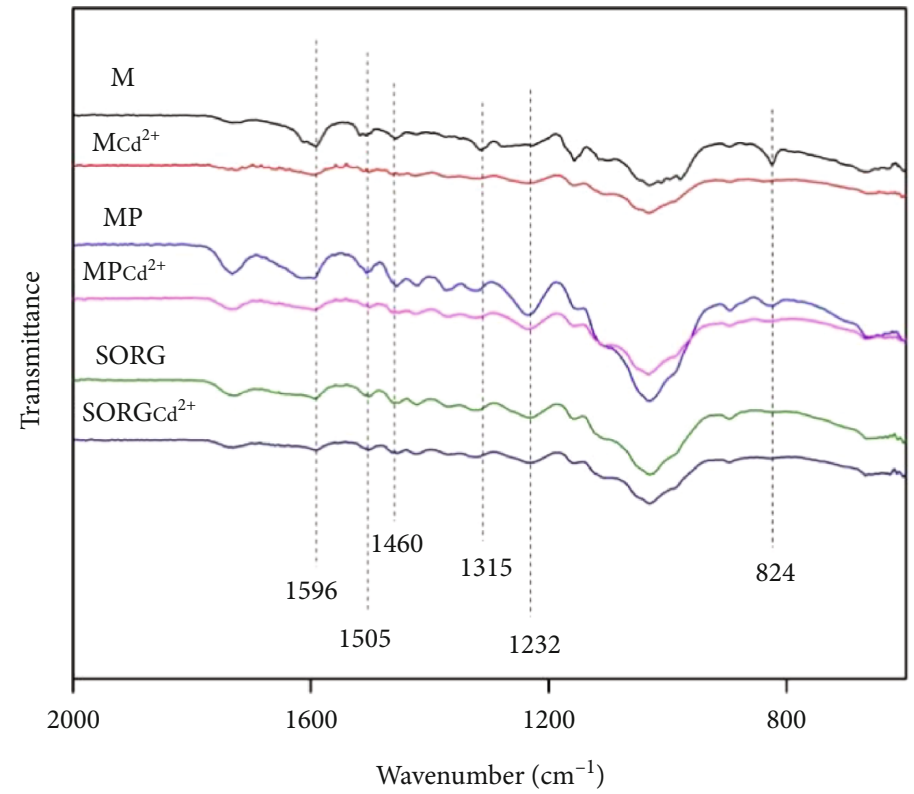

(b)

FIgURE 5: ATR-FTIR spectra of wood waste samples before (M, MP, and SORG) and after cadmium adsorption $\left(\mathrm{MCd}^{2+}, \mathrm{MPCd}^{2+}\right.$, and SORGCd ${ }^{2+}$ ): (a) $4000-600 \mathrm{~cm}^{-1}$ and (b) $2000-600 \mathrm{~cm}^{-1}$.

carboxylate and $\mathrm{Cd}^{2+}$ should not be neglected in the overall mechanism since some carboxyl groups may appear as deprotonated carboxylates at a $\mathrm{pH}$ of 5.50. According to Harvy et al. [40], carbonyl groups may be involved in the cation- $\pi$ binding mechanism of the $\mathrm{Cd}^{2+}$; so, the role of the aldehyde groups participating in such interactions could not be ruled out.

3.5. Kinetic Study. In the next step of the current investigation, the wood waste samples that possess the highest (mulberry, sample M) and the lowest (myrobalan plum, sample MP) adsorption potential (in further text: $q$ ) were selected to study the influence of contact time on their $q$ toward cadmium ions $\left(c_{0}=55 \mathrm{mg} / \mathrm{l}\right)$. As is presented in Figure 7, the adsorption of cadmium ions onto mulberry and myrobalan plum is a relatively fast process since, in the first hour of contact time, about $89 \%$ and $80 \%$ of their $q_{e}$ were reached, while the equilibrium was attained after four hours of contact time.

The kinetic data were fitted with pseudo-first and pseudo-second-order kinetic models to describe the rate of the adsorption process on the wood waste samples. The results given in Figure 7 revealed that the kinetic data obtained for myrobalan plum (sample MP) fit better with the pseudo-second-order model, while mulberry (sample 
M) showed a similar fit with both kinetic models. However, the calculated $q_{e}$ values $\left(q_{e, \text { cal }}\right)$ (see Table 3$)$ along with the nonlinear curve fitting (Figure 7 ) show that the adsorption for both samples follows the pseudo-second-order kinetic model, indicating that the adsorption is mediated by chemical forces. In other words, the adsorption/binding was established through sharing or exchange of electrons between the adsorbate and the adsorbent, as ionic exchanges [41], which was previously confirmed by the ATR-FTIR spectra (i.e., decreasing the peaks' intensities), Figure 6 . Additionally, the pseudo-second rate constant $\left(k_{2}\right)$ values indicate that the adsorption rate is 4 times higher in the case of the myrobalan plum $\left(k_{2}=0.032 \mathrm{~g} / \mathrm{mg} \mathrm{min}\right)$ compared with the mulberry $\left(k_{2}=0.008\right)$.

3.6. Thermodynamic Study. Besides initial solution $\mathrm{pH}$, initial ion concentration, and contact time, temperature represents another important factor influencing the wood waste samples $q$ towards $\mathrm{Cd}^{2+}$. Therefore, the adsorption experiments for the samples M and MP were conducted at three different temperatures $\left(25,35\right.$, and $45 \mathrm{C}^{\circ}$, i.e., $298.15,308.15$, and $318.15 \mathrm{~K})$, Figure 8.

Data obtained from adsorption experiments performed at different temperatures (Figure 8) were used to calculate the main thermodynamic parameters (i.e., standard Gibbs energy change $\Delta G^{\circ}$, standard enthalpy $\Delta \mathrm{H}^{\circ}$, and standard entropy $\Delta S^{\circ}$ ) of $\mathrm{Cd}^{2+}$ adsorption onto selected samples (Table 5).

As listed in Table 5, the positive $\ln \mathrm{K}_{\mathrm{eq}}$ values along with the negative $\Delta G^{\circ}$ and positive $\Delta S^{\circ}$ calculated for all considered temperatures, pointed out that the $\mathrm{Cd}^{2+}$ adsorption onto $\mathrm{M}$ and MP is spontaneous. Moreover, the negative $\Delta H^{\circ}$ values confirm that the adsorption process is of exothermic character.

3.7. The Effect of Cosolutes on the $\mathrm{Cd}^{2+}$ Adsorption onto Mulberry. It is well known that the different cosolutes may influence the $\mathrm{Cd}^{2+}$ adsorption onto mulberry. Therefore, two real matrixes, namely, tap water and water from the Sava river (Belgrade, Republic of Serbia), were prepared by adding $55 \mathrm{mg} / \mathrm{l}$ cadmium (with and without $\mathrm{pH}$ adjustment).

Based on the results given in Table 6, the mulberry adsorption capacities for $\mathrm{Cd}^{2+}$ are somewhat lower when the real waters (tap and Sava river waters) were used as matrixes. Such results were expected since the real waters contain calcium and magnesium ions (as was given in the experimental part of the manuscript) which compete for mulberry wood waste active sites.

3.8. Comparison of Wood Waste Adsorption Capacities for $\mathrm{Cd}^{2+}$ with the Adsorption Capacities of Other Lignocellulosic Materials. Taking into account that the $\mathrm{Cd}^{2+}$ adsorption conditions (such as initial metal ion concentration, solution $\mathrm{pH}$, contact time, temperature, and adsorbent dosage) used in the current study differ from those presented in other studies, it is very difficult to compare the wood waste $q$ with the $q$ obtained for other lignocellulosic materials. However, similar adsorption conditions (solution $\mathrm{pH}$, adsorbent dosage, and

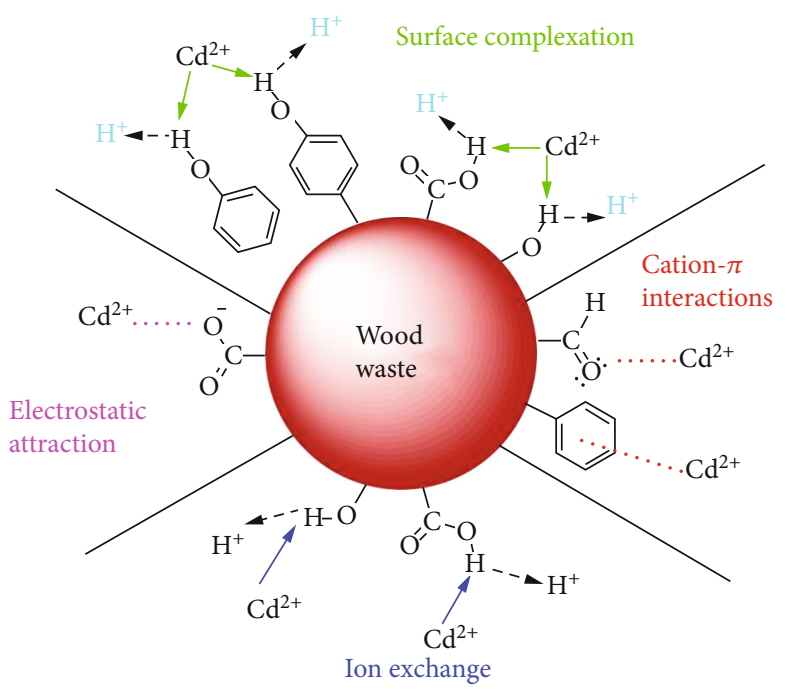

Figure 6: Schematic representation of a possible mechanism of binding $\mathrm{Cd}^{2+}$ onto wood waste.

initial cadmium concentration) allow us to compare the results obtained for the $q$ of wood waste samples and hemp fibers [42]. Namely, the observed raw hemp fiber $q$ was $6.63 \mathrm{mg} / \mathrm{g}\left(c_{0}=22.5 \mathrm{mg} / \mathrm{l}\right)$, which is about $54 \%$ lower than those of mulberry $\left(q=10.24 \mathrm{mg} / \mathrm{g}, c_{0}=25 \mathrm{mg} / \mathrm{l}\right)$ and in line with those of POBO sample $(q=6.88 \mathrm{mg} / \mathrm{g})$, Figure 3 . Loiacono et al. [14] reported two times higher maximum adsorption capacity $\left(q_{\max }=27.5 v s .12 .62 \mathrm{mg} / \mathrm{g}\right)$ of hemp-based felt which could be ascribed to the three times higher adsorbent dosage and two times lower solution volume $(1.5 \mathrm{~g} / 100 \mathrm{ml}$ vs. $0.5 \mathrm{~g} / 200 \mathrm{ml})$. Langmuir maximum adsorption capacities $\left(q_{\max }\right)$ of chemically modified (using $\mathrm{NaOH}, \mathrm{HNO}_{3}$, and $\mathrm{H}_{2} \mathrm{SO}_{4}$ ) sugarcane bagasse and wheat straw ranged from $1.5-2.2 \mathrm{mg} / \mathrm{g}$ to $2.5-3.8 \mathrm{mg} / \mathrm{g}$, respectively [43]. Also, significantly lower $\mathrm{Cd}^{2+}$ adsorption was observed by Mahmoodul-Hassan [44] (2.87 mg/g) for Picea smithiana sawdust and Zadeh et al. [45] for eucalyptus sawdust $(2.72 \mathrm{mg} / \mathrm{g})$. In the newest published paper, Gunjal [46] studied the $\mathrm{Cd}^{2+}$ adsorption $\left(c_{0}=25 \mathrm{mg} / \mathrm{l}\right)$ onto various lignocellulosic materials, whereby $q_{\max }$ of the peanut shell, corn cob, sawdust, and paddy husk was in the range of $1.80-2.07 \mathrm{mg} / \mathrm{g}$.

3.9. Antibacterial Activity of Wood Waste Samples. Wastewater treatment processes are designed to reduce the concentration of contaminants, including heavy metal ions before their discharge to receiving water. However, in many cases, these effluents contain a significant amount of pathogenic bacteria presenting a threat to public health. In light of that, the antibacterial activity of wood waste samples was investigated against Gram-negative bacteria E. coli and Gram-positive bacteria S. aureus, Table 7.

All wood waste samples possess a very high bacterial reduction (>99\%) for both tested bacteria. These results are expected having in mind the wood chemical composition, i.e., high content of lignin which polyphenolic compounds are responsible for observed antibacterial activity. Namely, 


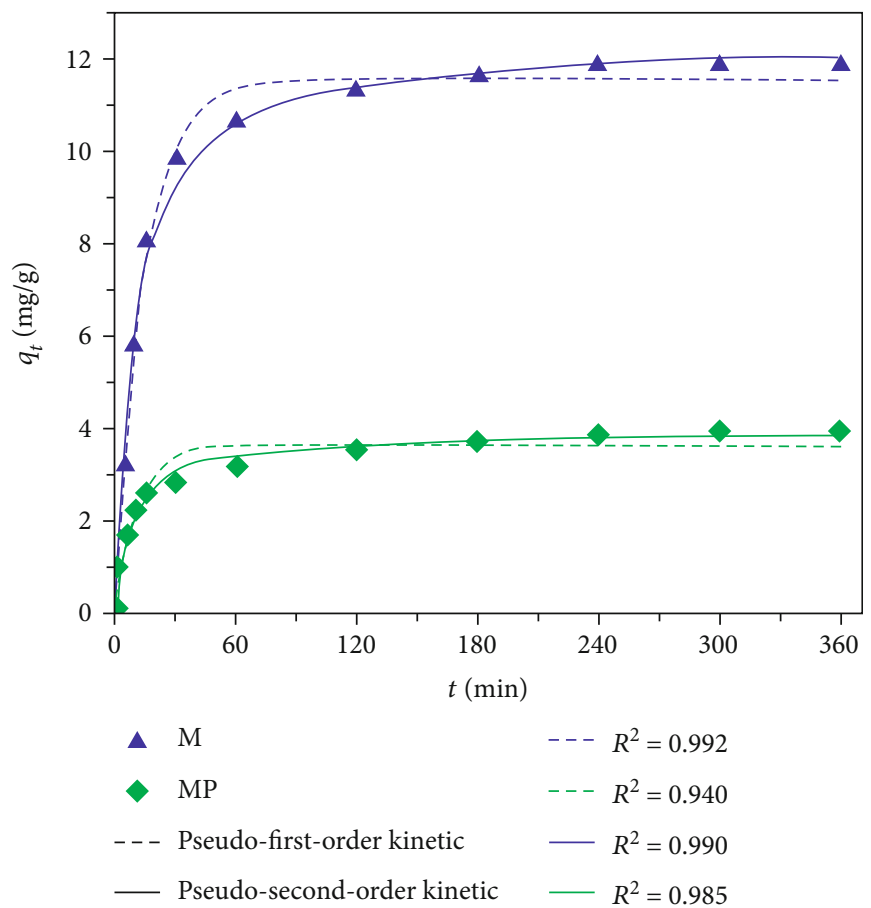

Figure 7: Kinetic data and nonlinear fit with pseudo-first and Pseudo-second-order kinetic for $\mathrm{Cd}^{2+}$ adsorption onto mulberry (M) and myrobalan plum (MP).

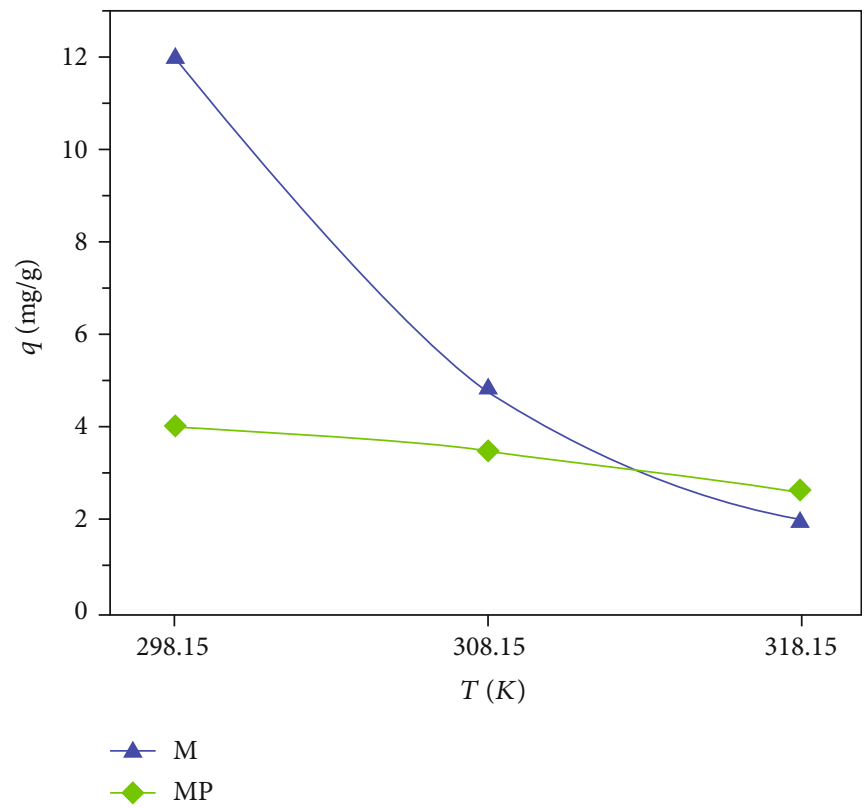

Figure 8: The effect of temperature $(T)$ on the cadmium adsorption $(q)$ onto mulberry $(\mathrm{M})$ and myrobalan plum (MP).

they cause cell membrane damage and lysis of bacteria with subsequent release of their cell contents [47]. Based on the results presented in this section, it can be assumed that all studied wood waste samples (i.e., alternatives' and oaks' staves) can be used as adsorbents for heavy metal ions (such as $\mathrm{Cd}^{2+}$ ) present in effluents at trace levels as well as for water disinfection (from E. Coli and S. aureus).

\section{Conclusions}

In the last two decades, the requirements for wood casks at the Balkan were expanded, and therefore, the amount of wood waste (such as alternatives' and oaks' staves) in this geographical area considerably increased. In this investigation, the possibility to revalue the wood waste (such as 
TABLE 5: Thermodynamic parameters for the $\mathrm{Cd}^{2+}$ adsorption onto mulberry (M) and myrobalan plum (MP).

\begin{tabular}{lccccc}
\hline Sample & Temperature, K & $\ln K_{\mathrm{eq}}$ & $\begin{array}{c}\Delta G^{\circ}, \\
\mathrm{kJ} / \mathrm{mol}\end{array}$ & $\begin{array}{c}\Delta H^{\circ}, \\
\mathrm{kJ} / \mathrm{mol}\end{array}$ & $\begin{array}{c}\Delta S^{\circ}, \\
\mathrm{J} / \mathrm{mol} \mathrm{K}\end{array}$ \\
\hline \multirow{3}{*}{$\mathrm{M}$} & 298.15 & 6.061 & -15.07 & -0.730 & 2.814 \\
& 308.15 & 4.716 & -12.12 & & \\
& 318.15 & 3.693 & -9.79 & & \\
$\mathrm{MP}$ & 298.15 & 4.476 & -11.13 & -3.595 & 1.406 \\
& 308.15 & 4.243 & -10.78 & & \\
\hline
\end{tabular}

TABLE 6: Comparison between the mulberry wood waste adsorption capacities for $\mathrm{Cd}^{2+}$ in different matrixes.

\begin{tabular}{lcc}
\hline Matrix & $\begin{array}{c}\text { Without } \mathrm{pH} \\
\text { adjustment }\end{array}$ & $\begin{array}{c}\text { At a } \mathrm{pH} \\
\text { of } 5.50\end{array}$ \\
\hline Aqueous solution, mg/g & 5.245 & 11.921 \\
Tap water, mg/g & 4.003 & 8.993 \\
Water from Sava river, mg/g & 4.296 & 10.921 \\
\hline
\end{tabular}

TABLE 7: Antibacterial activity of wood waste samples.

\begin{tabular}{lcccc}
\hline & \multicolumn{5}{c}{ Number of microbial colonies, } \\
Wood samples & \multicolumn{2}{c}{ CFU/ml, and microbial reduction, \% } \\
& $\begin{array}{c}\text { E. coli } \\
(\mathrm{CFU} / \mathrm{ml})\end{array}$ & $\begin{array}{c}\text { E. coli } \\
(\%)\end{array}$ & $\begin{array}{c}\text { S. aureus } \\
(\mathrm{CFU} / \mathrm{ml})\end{array}$ & $\begin{array}{c}\text { S. aureus } \\
(\%)\end{array}$ \\
\hline BL & 0 & 99.99 & 0 & 99.99 \\
M & 0 & 99.99 & 0 & 99.99 \\
MP & $1 \cdot 10^{3}$ & 99.92 & 0 & 99.99 \\
SORG & 0 & 99.99 & $1.5 \cdot 10^{5}$ & 99.53 \\
POGR & 0 & 99.99 & 0 & 99.99 \\
POBO & 0 & 99.99 & 0 & 99.99 \\
\hline
\end{tabular}

$C_{0}($ E. coli $)=1.3 \times 10^{6} \mathrm{CFU} / \mathrm{ml}$. $C_{0}($ S. aureus $)=3.2 \times 10^{7} \mathrm{CFU} / \mathrm{ml}$.

alternatives' and oaks' staves) from Balkan cooperage was examined. Cadmium was chosen as a model ion to test the ability of wood waste for heavy metal removal from an aqueous solution, while the samples' antibacterial activity was tested against E. coli and $S$. aureus to study the possibility of simultaneous wastewater disinfection. Cadmium adsorption onto wood waste increased (from 1.9-5.0 up to 4.0$11.9 \mathrm{mg} / \mathrm{g}$ ) with increasing its initial concentration (from 15 up to $55 \mathrm{mg} / \mathrm{l}$ ). Based on the equilibrium data, Langmuir adsorption isotherm was found as the most suitable model for describing the interaction between cadmium ions and wood waste samples. This isotherm model implies a monolayer coverage of cadmium ions over a homogeneous wood waste surface. Good connections among the samples' maximum adsorption capacities, their crystallinity index, and crystallite sizes were found. Namely, with increasing the content of amorphous regions, crystallite size, and amount of functional groups, the wood waste samples' adsorption capacity increases too. According to ATR-FTIR spectra, aldehyde, carboxyl, hydroxyl, and phenyl groups present on the wood waste surface are involved in $\mathrm{Cd}^{2+}$ adsorption which proceeds via the interplay of the complexation, cation- $\pi$ interactions, and ion-exchange mechanisms. Mulberry and myrobalan plum showed about $89 \%$ and $80 \%$ of the total uptake capacity of cadmium within the first hour of contact time, while the equilibrium was attained after four hours of contact time. As indicated by the applicability of the pseudo-second-order model, cadmium adsorption was mediated by chemical forces. Thermodynamic parameters revealed the spontaneous and exothermic character of cadmium ion adsorption onto mulberry and myrobalan plum. All alternatives and oaks provide maximum bacterial reduction (>99\%) for E. coli and S. aureus making them appropriate for simultaneous cadmium removal and wastewater disinfection.

\section{Data Availability}

Aleksandra Ivanovska (e-mail: aivanovska@tmf.bg.ac.rs) should be contacted to request the data.

\section{Conflicts of Interest}

The authors declare that there is no conflict of interest regarding the publication of this paper.

\section{Acknowledgments}

The authors thank Jelena Lađarević (Faculty of Technology and Metallurgy, University of Belgrade) for schematic representation and discussion of a possible mechanism of binding $\mathrm{Cd}^{2+}$ onto wood waste and Steva Lević (Faculty of Agriculture, University of Belgrade) for obtaining ATR-FTIR spectra. The authors are grateful to the Ministry of Education, Science, and Technological Development of the Republic of Serbia [Contract No. 451-03-9/202114/200287, 451-03-9/2021-14/200135, 451-03-9/2021-14/ 200026, 451-03-9/2021-14/200051, 451-03-9/2021-14/200 168] for funding the study.

\section{References}

[1] A. Martínez-Gil, M. del Alamo-Sanza, R. Sánchez-Gómez, and I. Nevares, "Different woods in cooperage for oenology: a review," Beverages, vol. 4, no. 4, p. 94, 2018.

[2] S. Pecić, M. Veljović, S. Despotović et al., "Effect of maturation conditions on sensory and antioxidant properties of old Serbian plum brandies," European Food Research and Technology, vol. 235, no. 3, pp. 479-487, 2012.

[3] M. Perić, D. Antonijević, M. Komatina, B. Bugarski, and M. Rakin, "Life cycle assessment of wood chips supply chain in Serbia," Renewable Energy, vol. 155, pp. 1302-1311, 2020.

[4] T. Map, 2020, December 2020, https://www.trademap.org/ Index.aspx.

[5] E. G. Nichols, "Current and future opportunities for forest land application systems of wastewater," in Phytoremediation, A. Ansari, S. Gill, R. Gill, G. Lanza, and L. Newman, Eds., vol. 4, pp. 153-173, Springer, Cham, 2016.

[6] R. Selvasembian, W. Gwenzi, N. Chaukura, and S. Mthembu, "Recent advances in the polyurethane-based adsorbents for the decontamination of hazardous wastewater pollutants," 
Journal of Hazardous Materials, vol. 417, article 125960, 2021.

[7] S. Özdemir, E. Kılınç, A. Poli et al., "Extraction of $\mathrm{Cu}^{2+}$ and $\mathrm{Co}^{2+}$ by using Tricholoma populinum loaded onto Amberlite XAD-4," International journal of Environmental Science and Technology, vol. 18, no. 1, pp. 185-194, 2021.

[8] F. A. Dawodu, B. M. Akpan, and K. G. Akpomie, "Sequestered capture and desorption of hexavalent chromium from solution and textile wastewater onto low cost Heinsia crinita seed coat biomass," Applied Water Science, vol. 10, no. 1, p. 32, 2020.

[9] A. Buha, D. Wallace, V. Matovic et al., "Cadmium exposure as a putative risk factor for the development of pancreatic cancer: three different lines of evidence," Biomed Research International, vol. 2017, article 1981837, p. 8, 2017.

[10] V. R. Djordjevic, D. R. Wallace, A. Schweitzer et al., "Environmental cadmium exposure and pancreatic cancer: evidence from case control, animal and in vitro studies," Environmental International, vol. 128, pp. 353-361, 2019.

[11] World Health Organization WHO, "Guidelines for drinkingwater quality," vol. 1, 2008December 2020, https://www.who .int/water_sanitation_health/dwq/fulltext.pdf.

[12] A. Ivanovska, B. Dojcinovic, S. Maletic, L. Pavun, K. Asanovic, and M. Kostic, "Waste jute fabric as a biosorbent for heavy metal ions from aqueous solution," Fibers and Polymers, vol. 21, no. 9, pp. 1992-2002, 2020.

[13] C. Sahu and S. Basti, "Trace metal pollution in the environment: a review," International Journal of Environmental Science and Technology, vol. 18, no. 1, pp. 211-224, 2021.

[14] S. Loiacono, G. Crini, G. Chanet, M. Raschetti, V. Placet, and N. Morin-Crini, "Metals in aqueous solutions and real effluents: biosorption behavior of a hemp-based felt," Journal of Chemical Technology and Biotechnology, vol. 93, no. 9, pp. 2592-2601, 2018.

[15] S. Rangabhashiyam and K. Vijayaraghavan, "Biosorption of $\mathrm{tm}(\mathrm{III})$ by free and polysulfone-immobilized Turbinaria conoides biomass," Journal of Industrial and Engineering Chemistry, vol. 80, pp. 318-324, 2019.

[16] S. Rangabhashiyam, S. Sayantani, and P. Balasubramanian, "Assessment of hexavalent chromium biosorption using biodiesel extracted seeds of Jatropha sp., Ricinus sp. and Pongamia sp," International journal of Environmental Science and Technology, vol. 16, no. 10, pp. 5707-5724, 2019.

[17] Z. Kovacova, S. Demcak, M. Balintova, C. Pla, and I. Zinicovscaia, "Influence of wooden sawdust treatments on $\mathrm{Cu}(\mathrm{II})$ and $\mathrm{Zn}(\mathrm{II})$ removal from water," Materials, vol. 13, no. 16 , article $3575,2020$.

[18] N. Morin-Crini, J. N. Staelens, S. Loiacono, B. Martel, G. Chanet, and G. Crini, "Simultaneous removal of Cd, Co, $\mathrm{Cu}, \mathrm{Mn}, \mathrm{Ni}$, and $\mathrm{Zn}$ from synthetic solutions on a hempbased felt. III. Real discharge waters," Journal of Applied Polymer Science, vol. 137, no. 24, article 48823, 2020.

[19] C. Chu, E. C. Ryberg, S. K. Loeb, M.-J. Suh, and J.-H. Kim, "Water disinfection in rural areas demands unconventional solar technologies," Accounts of Chemical Research, vol. 52, no. 5, pp. 1187-1195, 2019.

[20] A. Smailagić, P. Ristivojević, I. Dimkić et al., "Radical scavenging and antimicrobial properties of polyphenol rich waste wood extracts," Foods, vol. 9, no. 3, p. 319, 2020.

[21] A. D. French, "Idealized powder diffraction patterns for cellulose polymorphs," Cellulose, vol. 21, no. 2, pp. 885-896, 2014.
[22] S. Nam, A. D. French, B. D. Condon, and M. Concha, "Segal crystallinity index revisited by the simulation of X-ray diffraction patterns of cotton cellulose I $\beta$ and cellulose II," Carbohydrate Polymers, vol. 135, pp. 1-9, 2016.

[23] T. Saito and A. Isogai, "TEMPO-mediated oxidation of native cellulose. The effect of oxidation conditions on chemical and crystal structures of the water-insoluble fractions," Biomacromolecules, vol. 5, no. 5, pp. 1983-1989, 2004.

[24] A. Ivanovska, D. Cerovic, N. Tadic, I. Jankovic Castvan, K. Asanovic, and M. Kostic, "Sorption and dielectric properties of jute woven fabrics: effect of chemical composition," Industrial Crops and Products, vol. 140, article 111632, 2019.

[25] A. Ivanovska, K. Asanovic, M. Jankoska, K. Mihajlovski, L. Pavun, and M. Kostic, "Multifunctional jute fabrics obtained by different chemical modifications," Cellulose, vol. 27, no. 14, pp. 8485-8502, 2020.

[26] M. E. Alañón, L. Castro-Vázquez, M. C. Díaz-Maroto, I. Hermosín-Gutiérrez, M. H. Gordon, and M. S. Pérez-Coello, "Antioxidant capacity and phenolic composition of different woods used in cooperage," Food Chemistry, vol. 129, no. 4, pp. 1584-1590, 2011.

[27] R. M. Rowell, R. Pettersen, and M. A. Tshabalala, "Cell wall chemistry," in Handbook of Wood Chemistry and Wood Composites, R. M. Rowell, Ed., pp. 33-72, CRC Press, Boca Raton, 2012.

[28] A. Smailagić, S. Veljović, U. Gašić et al., "Phenolic profile, chromatic parameters and fluorescence of different woods used in Balkan cooperage," Industrial Crops and Products, vol. 132, pp. 156-167, 2019.

[29] A. M. Rizzuti, K. D. Mouzone, L. W. Cosme, and A. D. Cohen, "Utilising highly characterised peats to remove cadmium from aqueous solutions," Mires and Peat, vol. 21, article 21, pp. 110, 2018.

[30] P. Semeraro, P. Fini, M. D’Addabbo, V. Rizzi, and P. Cosma, "Removal from wastewater and recycling of azo textile dyes by alginate-chitosan beads," International Journal of Environment, Agriculture and Biotechnology, vol. 2, no. 4, pp. 18351850, 2017.

[31] J. H. Park, J. H. Eom, S. L. Lee et al., "Exploration of the potential capacity of fly ash and bottom ash derived from wood pellet-based thermal power plant for heavy metal removal," Science of the Total Environment, vol. 740, no. 20, article 140205, 2020.

[32] A. Khan, M. A. Hussein, F. M. Alsheri, A. A. Alamry, and A. M. Asiri, "A new class of polyethylene glycol-grafted graphene carbon nanotube composite as a selective adsorbent for Au(III)," Waste and Biomass Valorization, vol. 12, no. 2, pp. 937-946, 2021.

[33] Y. Wu, J. Zhou, Q. Huang et al., "Study on the colorimetry properties of transparent wood prepared from six wood species," ACS Omega, vol. 5, no. 4, pp. 1782-1788, 2020.

[34] C. Ganne-Chédeville, A. S. Jääskeläinen, J. Froidevaux, M. Hughes, and P. Navi, "Natural and artificial ageing of spruce wood as observed by FTIR-ATR and UVRR spectroscopy," Holzforschung, vol. 66, pp. 163-170, 2011.

[35] B. S. Gupta, B. P. Jelle, and T. Gao, "Wood facade materials ageing analysis by FTIR spectroscopy," Proceedings of the Institution of Civil Engineers-Construction Materials, vol. 168, no. 5, pp. 219-231, 2015.

[36] H. Zhang, P. Liu, S. M. Musa, C. Mai, and K. Zhang, "Dialdehyde cellulose as a bio-based robust adhesive for wood 
bonding," ACS Sustainable Chemistry \& Engineering, vol. 7, no. 12, pp. 10452-10459, 2019.

[37] X. Yang, Y. Wan, Y. Zheng et al., "Surface functional groups of carbon-based adsorbents and their roles in the removal of heavy metals from aqueous solutions: a critical review," Chemical Engineering Journal, vol. 366, pp. 608-621, 2019.

[38] P. Yang, L. Yang, Y. Wang, L. Song, J. Yang, and G. Chang, "An indole-based aerogel for enhanced removal of heavy metals from waterviathe synergistic effects of complexation and cation $-\pi$ interactions," Journal of Materials Chemistry A, vol. 7, no. 2, pp. 531-539, 2019.

[39] Y. Xia, H. Liu, Y. Guo, Z. Liu, and W. Jiao, "Immobilization of heavy metals in contaminated soils by modified hydrochar: efficiency, risk assessment and potential mechanisms," Science of the Total Environment, vol. 685, pp. 1201-1208, 2019.

[40] O. R. Harvey, B. E. Herbert, R. D. Rhue, and L. Kuo, "Metal interactions at the biochar-water interface: energetics and structure-sorption relationships elucidated by flow adsorption microcalorimetry," Environmental Science and Technology, vol. 45, no. 13, pp. 5550-5556, 2011.

[41] N. A. Akbar, H. A. Aziz, and M. Y. D. Alazaiza, "Effectiveness of Fe, Mn, UV254 and colour removal from pre-ozonated groundwater using anthracite coal," International Journal of Environmental Research, vol. 15, no. 2, pp. 245-259, 2021.

[42] B. Pejic, M. Vukcevic, M. Kostic, and P. Skundric, "Biosorption of heavy metal ions from aqueous solutions by short hemp fibers: effect of chemical composition," Journal of Hazardous Materials, vol. 164, no. 1, pp. 146-153, 2009.

[43] M. Mahmood-ul-Hassan, V. Suthar, E. Rafique, R. Ahmad, and M. Yasin, "Kinetics of cadmium, chromium, and lead sorption onto chemically modified sugarcane bagasse and wheat straw," Environmental Monitoring and Assessment, vol. 187, article 470, 2015.

[44] M. Mahmood-ul-Hassan, M. Yasin, M. Yousra, R. Ahmad, and S. Sarwar, "Kinetics, isotherms, and thermodynamic studies of lead, chromium, and cadmium bio-adsorption from aqueous solution onto Picea smithiana sawdust," Environmental Science and Pollution Research, vol. 25, no. 13, pp. 1257012578, 2018.

[45] B. S. Zadeh, H. Esmaeili, R. Foroutan, S. M. Mousavi, and S. A. Hashemi, "Removal of cd from aqueous solution using eucalyptus sawdust as a bio-adsorbent: kinetic and equilibrium studies," Journal of Environmental Treatment Techniques, vol. 8, no. 1, pp. 112-118, 2020.

[46] A. Gunjal, "Kinetics Study for the Removal of Heavy Metals by the Agroindustry by-Products," Proceedings of the Indian National Science Academy, vol. 87, no. 1, pp. 57-62, 2021.

[47] J. L. Espinoza-Acosta, P. I. Torres-Chávez, B. Ramírez-Wong, C. M. López-Saiz, and B. Montaño-Leyva, "Antioxidant, antimicrobial, and antimutagenic properties of technical lignins and their applications," BioResources, vol. 11, no. 2, pp. 5452-5481, 2016. 